\title{
Argument-Driven Inquiry (ADI): The Way to Develop Junior High School Student's Argumentation Skills in Science Learning
}

\author{
Annisa Nurramadhani \\ Magister of Science Education \\ Indonesia University of Education, UPI \\ Bandung, Indonesia \\ annisanurramadhani@student.upi.edu
}

\author{
Hernani \\ Department of Chemistry Education \\ Indonesia University of Education, UPI \\ Bandung, Indonesia
}

\author{
Taufik Rahman \\ Department of Biology Education \\ Indonesia University of Education, UPI \\ Bandung, Indonesia
}

\begin{abstract}
Argumentation skills or the skills of making the argument on the process of learning science is required for the development of the concept and practicing how to think about a concept that is so that the students can find the fact, concept and other things related to whole science in students' long-term memory. But the result of argumentation every students are different. It is depend on academic level of students. There are higher acheiver and lower acheiver. The argumentation skills inboth of classes are not develop very well because several teachers who did not provide an opportunity to the students to give the opinion of the knowledge. Based on the issue, this research purposes is to investigate the argumentation skills improvement on both of classes with different academic level by applying learning model based on the argument that is Argument-Driven Inquiry (ADI) in science learning. The method of this research is used quasi experiment method with the matching-only pretest-posttest comparison group design. Research subject are junior high school students from State Junior High School inIndramayu grades VII. VII-B can be called unggulan class because all students are high achiever, while VII$H$ is regular class because the students in this class are come from middle-lower achiever. The result of this research shows thatthe argumentation skills in both of classes are developed to the positive ways. The average $\mathrm{N}$-gain value for whole result written argumentation skills in unggulan class has high improvement criteria (0.73)and regular class has middleimprovement criteria (0.58). Aspect of written argumentation skills improvement in both of classes has different result. All the improvement criteria result for written argumentation skills aspect in unggulan class has outperformed than regular class, except warrant aspect both classes has the lowest value among other aspect with middle criteria. Dialogic argumentation skills result alsohas better development for unggulan class rather than regular class. Even though the result shows like that, it can be conclude by implementing learning model ADI, student's argumentation in written or dialogic can be developed to the positive ways.
\end{abstract}

Keywords-ADI; Argumentation Skill; Science Learning; Academic Level

\section{INTRODUCTION}

One of the goals of science is to provide the opportunity for the students to build on the understanding the natural phenomenon that is wider in scope, the concepts of science and the principles of science is very important in the application of daily life activities every day [1]. The implementation of science lessons in the classroom is not only limited to receive the concept that was given by the teacher but the students are able to find the concept itself as a result of the process of his discovery and students' higher order thinking level can be trained.

One of the skills which can be developed to achieve quality education to build the concept of science and practicing students' higher order thinking level is argumentation skills. Argumentation skills on the process of learning science is required for the development of the concept and praticing how to think about a concept that is so that the students can find the fact, concept and other things related to whole science and saved in the students' long-term memory. In other hand, argumentation is important in learning science because science is not merely the presentation of the fact but build arguments, consider, debating the various phenomenon of science [2].

In reality, the students' ability to make the argument still can't be develop because there are several teachers who did not provide an opportunity to the students to give the opinion of the knowledge that they have already got or give a comment and critique on what teachers explain especially in learning science [3]. So that the students only receive an explanation of the teachers without any comments whether that is given is the correct explanation or any information that is less accurate. The result is the student's argumentation ability is less unearthed.

Argumentation skill also depend on the characteristic of students itself. The characterictic means that the ability in cognitive of students in the level of ability lower achiver, 
middle acheiver, and higher acheiver. This is very important to be researced because the ability of students can influence how the students deliver their argument. As like the researchfrom several researcher that said the level of student's academic level are gained from the result of their past academic testand can be influence to how they deliver their argument, motivation, and higher order thinking[3 and 4]. This research is different with others that the development of student's academic level only as side result, not as main result and focus on that issue [4, 5 and 6], and also conduct with ADI learning model, but not in science intgrated learning, they only do their research in Physiscs, Biology, Chemistry, or others field [4, 7, 8 and 9].

To solve this problem, the ability to make an argument can be practiced in learning science in order to increase and develop argumentation skill of students with different academic level. One of the ways to practices argumentation skills is by implementing learning model based on the argument that is Argument-Driven Inquiry (ADI). ADI can increase the students' argumentation skills. In line with the research that has been done by some researchers with the result that the same applies learning model ADI in learning science can improve argumentation skills [5, 6 and 8]. So, it can build the research questions namely how ADI can improve students' argumentation skills in higher acheiver (unggulan class) and middle-lower acheiver (regular class)?

\section{A. Argument-Driven Inquiry (ADI)}

Argument-Driven Inquiry (ADI) is a model of teaching which is based on the inquiry to learning with laboratory activity that will make the students more scientific and authentict and critical. This learning model can build the logic and critical thinking of students by emphasizing to the role of the argument itself is formed and validate scientific thought [5 and 9]. From the explanation above, researchers have developed a learning model Argument-Driven Inquiry (ADI) into eight stages according to references [8]:

1) The task identification, beginning phase where the teacher can ask instructions questions for laboratory experiment that will be conducted; 2) Build data analysis, at this stage the teacher helps students to build a better investigation through some reflective questions. By asking questions to the students that what they would do and why they do so; 3) make temporary arguments, on this steps teachers are asked to provide advice on data that is less complete, less consistent or less accurate. In addition, teachers can offer advice about how the students can analyze their data. So that students can be motivated to build a claim, evidence, and their reasoning in their arguments; 4) Arguments session, the students were asked to communicate data that has been obtained to other groups. All of the students were asked to participate actively involved in a discussion with minimal teacher intervention. Students are also asked to be able to criticize the arguments that are constructed by other groups; 5) create a report of the investigation results, after the argument session end, then the students are asked to create a report the results of their investigation. Teachers Remind the students that the draft which are they create this is for peer review so that the students are asked to make the draft or investigation results seriously; 6) double-blind peer review, teachers distribute students' draft report of investigation results per group to be given to the other groups so that the corrected by peers; 7) the revision of the report of investigation, the students are asked to revise their report based on what they have read and know from the results of the peer review earlier; 8) Reflective Discussion and explicit, students and teachers are together reflect on the learning that has been done. Then do the discussion related to the content that has already learned. After that the teacher gives the conclusion to the students.

From the steps that has been described, learning model of Argument-Driven Inquiry (ADI) can improve students argumentation skills. As the result of the research that has been done, learning model ADI can improve the ability to arrange students argument both orally and in writing [5, 7 and 9].

\section{B. Learning with Experiment and Argumentation Session Can Develop Student's Argumentation}

As has been described that ADI is a learning model based on the argument with the laboratory experiment inquiry. Laboratory experiment plays an important role in learning science because it can build a higher order thinking skills or (HOT). Through laboratory experiment, students are able to define variables and formulate the problem and determine the purpose of the draft procedures, interpreting data and create a conclusion. With experiment, students are able to claim scientific arguments from the question of the research that has been given and this can answer the hypothesis, alter the method and provide a feedback from what has been done during the experiment [5]. The idea is experiment laboratory activity is the basis of the argument in learning science [10].

In addition, in this learning model ADI on the steps of the arguments session, the students were asked to express their opinions. Then the other students criticize what has been put forward by their friends. From this activity, can be seen the students argumentation ability orally, namely in conveying the argument as claim, data, warrant, and backing. Based on the research results [11 and 12] stated that with practicing dialogic argumentation to the students and their argumentation skill will develop. When students conduct dialogic argumentation, so that stressed is the counterargument or other words are to criticize the opinions of others with evidences that they had, provided critical questions against their opponents. In addition, when debated in the dialog to deliver their opinions and the students are observing opponents' statement very detail and they will be proposed criticized based on evidence freely, so that their argumentation skills will be well developed [11] In the other hand, on the steps of learning model ADI can develop students written argumentation.

\section{Academic Level of Students}

Argumentation skill also depend on the characteristic of students itself. The characterictic means that the ability in cognitive of students in the level of ability lower achiver, middle acheiver, and higher acheiver. This is very important to be researced because the ability of students can influence how the students deliver their argument. As like the researchfrom several researcher that said the level of student's academic 
level are gained from the result of their past academic testand can be influence to how they deliver their argument, motivation, higher order thinking [3 and 4].

Usually, higher achiever class gives the better result for the argumentation than regular or middle-lower achiever. It is in a line with the research that said there is significant improvement of student's higher order thinking skill include argumentation skill, passing question, and critical thinking by all student's academic level, but highachiever shows better improvement than lower achiever [3 and 13].

\section{RESEARCH METHOD}

This research used quasi experiment method with the matching-only pretest-posttest comparison group design. The designs have two classes that all experiment classes but the differences in the student's achievement. One class for high achiever or unggulan class and the other one for middle-lower achiever or regular class. Before treatment, there is a pretest for argumentation skills that contain 6 problems with 24 questions about environmental pollution. After treatment, the students got posttest with the same problem in pretest.

Research subject are junior high school students from State Junior High School in Indramayu grades VII. VII-B can be called unggulan class because all students are high achiever (31 students), while VII-H is regular class because the students in this class are come from middle-lower achiever (32 students).

Data collection is used some instrument there are argumentation skills test that applied in pretest and posttest. There is a pretest for argumentation skills that contain 6 problems with 24 questions about environmental pollution and also posttest with the same problem in pretest.The questions for student's opinion about learning process with ADI model as additional data. Recording gained students dialogic argumentation skills during learning process.

Data analysis used N-Gain criteria test for investigate student's argumentation skills improvement on both classes. The analysis of dialogic argumentation skills is quality of argumentation based on the research [14]. The framework is shown in Table I.

TABLE I. ANALYTICAL FRAMEWORK USED FOR ASSESSING THE QUALITY OF ARGUMENTATION

\begin{tabular}{|l|l|}
\hline Level 1 & $\begin{array}{l}\text { Level } 1 \text { argumentation consists of arguments that are a simple } \\
\text { claim versus a } \\
\text { Counter-claim or a claim versus a claim. }\end{array}$ \\
\hline Level 2 & $\begin{array}{l}\text { Level } 2 \text { argumentations have arguments consisting of a claim } \\
\text { versus a claim withdata, warrants, or backings but do not contain } \\
\text { any rebuttals. }\end{array}$ \\
\hline Level 3 & $\begin{array}{l}\text { Level } 3 \text { argumentations have arguments with a series of claims } \\
\text { or counter-claimswith data, warrants, or backings with the } \\
\text { occasional weak rebuttal. }\end{array}$ \\
\hline Level 4 & $\begin{array}{l}\text { Level 4 argumentation shows arguments with a claim with a } \\
\text { clearly identifiable rebuttal. Such an argument may have several } \\
\text { claims and counter-claims. }\end{array}$ \\
\hline Level 5 & $\begin{array}{l}\text { Level } 5 \text { argumentation displays an extended argument with more } \\
\text { than onerebuttal. }\end{array}$ \\
\hline
\end{tabular}

\section{RESULT AND DISCUSSION}

\section{A. Student's Written Argumentation Skills}

The result of this research is about the improvement of student's argumentation skills in written and dialogical both from unggulan class and regular class. This is the result of students written argumentation skill in ungulan class and regular class is shown in Fig 1.

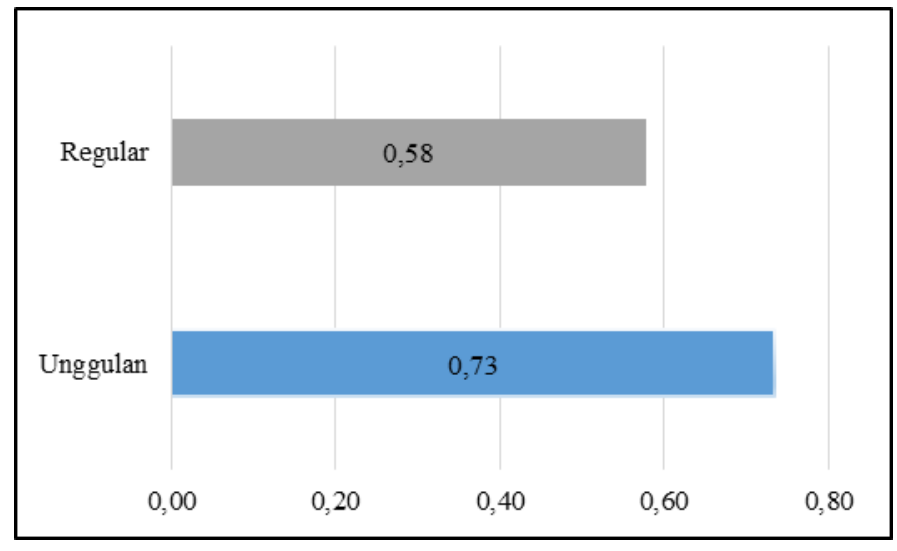

Fig. 1. Improvement of Student's Written Argumentation Skill from Unggulan Class and Regular Class

That result shows that there is the development of student's argumentation skills after the lesson using the learning model ADI (Inquiry Argument-Driven) both are unggulan class or in regular class. Seen from the results of the $\mathrm{N}$-gain average value in unggulan class has 0.73 (high criteria) and regular class 0.58 (middle criteria). It can be said that the science lesson by applying learning model ADI (Inquiry Argument-Driven) can improve the ability to arrange the argumentation students both in unggulan class and regular class. It is in a line with the research that said by implementing learning model ADI can improve student's argumentation skills[5, 6 and 8]. This learning model also a deliberate to build the atmosphere of the class that can help students to understand the explanation of the scientific explanation of how to provide an opinion with evidence of scientific, and comprehend the fact of scientific knowledge [9].With experiment, students are able to claim scientific arguments from the question of the research that has been given and this can answer the hypothesis, alter the method and provide a feedback from what has been done during the experiment [5]. The idea is experiment laboratory activity is the basis of the argument in learning science [10].

From the graph, it said that the criteria of improvement for unggulan class has different result from regular class. Unggulan class has high criteria, while regular class got middle criteria. It is becaused the level of academic ability of students who obtained from their academic test results and can affect their differences in deliver the argument, motivation self confidence and higher order thinking level [4 and 5]. This result has common with the other reasearch that said there are significanly improvement of higher order thinking level wich is argumentation skill in unggulan class has better than regular class [3 and 13]. 


\section{B. Student's Written Argumentation Skills in Aspect}

Based on the result above, not only whole result from argumentation skill of both of classes but every single aspect in argumentation skills such as claim, data, warrant, and backing are calculated and analyze. This is the result of argumentation aspect from unggulan class and regular class is shown in Fig 2.

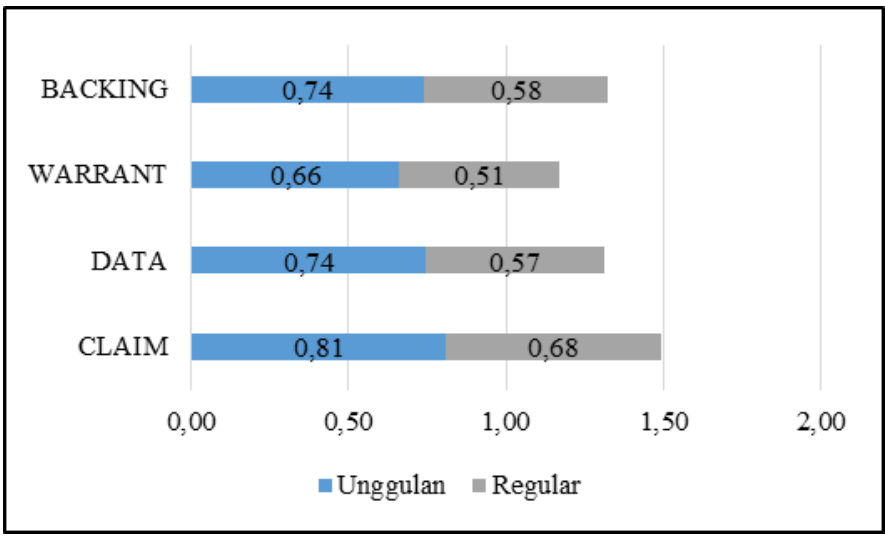

Fig. 2. Improvement of Student's Written Argumentation Skill in Aspect FromUnggulanClass and Regular Class

The result shows that all the aspect from argumentation skill from claim, data, and backing in unggulan class has improvement high criteria for the value $0.81 ; 0.74$ and 0.74 rather than in regular class that has improvementmiddle criteria with the value $0.68 ; 0.57$ and 0.58 . And the aspect of claim has higher result on both classes but the value of unggulan class has higher (0.81) than regular class (0.68). This is because of the claim, data, and backing that is stated by unggulan class is more correct rather than in regular class. These results also strengthen by the result of questionnaire of students' opinion about learning with argument. The result of indicator how to deliver the claim in regular class $71.3 \%$ and the precentage for unggulan class has higher result as $75.2 \%$.

But for the aspect of warrant, both of classes have the lowest value from other aspect. Both of class got the improvement middlecriteria with the value 0.66 for unggulan class and 0.51 for regular class. This is happened in a line with the result from questionnaire of students' opinion about learning with argument. The indicator aspects of warrant have the percentage of unggulan class and regular class with each percentage namely $70.8 \%$ for unggulan class and $63.3 \%$ for regular class.It can be said that most of the students both in the unggulan class and regular class have difficulties to relate the data and information that they have with the claim or statement that they create, especially in regular class. This is a line with the research that has been done that $51.5 \%$ of students from the total number of low grade less accurate in explaining warrant as evidence. This is due to the students in regular class has difficulties to stated warrant, also the higher classes has the same difficulties because of lack of elaborating the data that is associated with their claims and less accurate in connection for both aspect ${ }^{[9]}$.

\section{Student's Dialogic Argumentation Skill}

Beside the written argumentation, dialogical argumentation also has been analyzed from both of classes. This is the result of dialogic argumentation skills analyzed by every single level of quality argumentation shown in Fig 3.

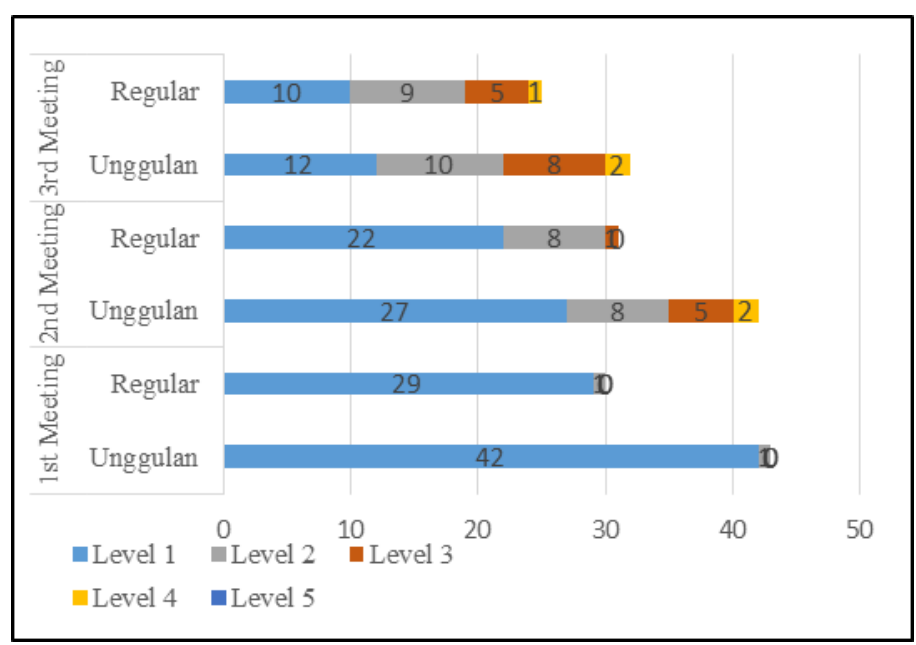

Fig. 3. Improvement of Student's Dialogical Argumentation Skill From Unggulan Class and Regular Class

From the Fig 3, the results are divided into three meeting. First meeting, both of classes only have level 1 and less level 2 and for level 3 also level 4 there has not appeared yet. Second meeting, level 1 on both of classes decreasing from first meeting while for level 2 has increase. Level 3 and level 4 there are differences between value in unggulan class and regular class. In unggulan class, those level already appearwhile in regular class still zero. The last meeting, level 1 has decreasing value from second meeting, level 2 and level 3 on both of class has increase. Especially in regular class, level 3 and level 4 in this meeting has already appeared and for unggulan class level 4 make decrease one point.

The level 1 has decreased in every meeting for both of classes. That happened because the quality of students' dialogical argumentations skills on both of classes has been developed, not only deliver simple claim but also they have already deliver claim with data, warrant, backing, even little bit rebuttal.The result is in aline with the result from the research [14] that the result of level 1 has decrease from $22 \%$ become $15 \%$. This is nice result because the students not only deliver the claim with simple claim.

Level 2 and level 3 has increase on both of classes in every single meeting. It is in a line with the research that saidthe ability of students to arrange their argumentation from the beginning until the last meeting, level 2 from $30 \%$ become $38 \%$ and level 3 from $40 \%$ become $55 \%$. It is because the students deliver their argument with evidence, warrant, and little bit rebuttal [14]. 
Different with level 2, level 3, and level 1, that level 4 has the lowest value. It is caused making rebuttal explicitly in science learning based on argumentation from students are spontaneously. The students are rare to deliver their argumentation perfectly but students just deliver simple reason with evidences. This is like the research that the students often deliver their argument only claim, data or claim with warrant [15]. The other reason, more than half lower students and several higher achiever students has difficulties to deliver the rebuttal against claim or counterclaim because rebuttal is harder than students' cognitive task for the most students [3].

Level 5 are not appearing on this research from both of classes. The level 5 is about more than one rebuttal. This is because, rebuttal are not practiced in this research. Rebuttal that appear in this research are only simple rebuttal that delivered by students spontaneously in argumentation session. In this research, the students practice about their argumentation only claim, data, warrant, and backing. Even though the result shows like that, can be said that dialogical argumentation skill of students are increase, not only dialogical but also written argumentation are increase too. Learning model ADI can improve the ability of students to arrange their argument orally and written [5, 7 and 9]. The implementing learning model ADI, argumentation skill of students in unggulan class and regular class can deveope to the positive ways.

\section{CONCLUSION}

From the discussion above, it can be conclude that learning model Argument- Driven Inquiry (ADI) can develop student's argumentation skill. The both of unggulan class and regular class have different characteristic of academic ability in students. Both of classes have improved in argumentation skills by written and dialogical. Although they have different improvement criteria that higher achiever has outperformed rather than middle-lower achiever, all students in both of classes make a better argumentation for their own

\section{References}

[1] Depdikbud. (2006). Panduan Penyusunan Kurikulum Tingkat Satuan Pendidikan Jenjang Pendidikan Dasar and Menengah. Jakarta: Baand Standar Nasional Pendidikan.
[2] Osborne, J., Erduran, S., and Simon, S. (2004). "Enhancing The Quality of Argumentation in School Science". Journal of Research in Science Teaching. 41 (10), 994-1020

[3] Lin,Shu-Sheng and Mintzes,J.J. (2010). Learning Argumentation Skills Through Instruction in Socioscientific Issues: The effect of Ability Level. International Journal of Science and Mathematics Education, 8 (6), 993-1017.

[4] Dori, Y. J., Tal, R. T., and Tsaushu, M. (2003). Teaching Biotechnology Through Case Studies - Can We Improve Higher Order Thinking Skills of Nonscience majors? Science Education. 87 (6), 767-793.

[5] Hasnunidah, N, et.al. (2015). Argument-Driven Inquiry with Scaffolding as Development Strategies of Argumentation and Critical Thinking Skill of Students in Lampung, Indonesia. American Journal of Educational Research. 3 (9), 1185 - 1192.

[6] Demircioglu,T and Ucar,S. (2015). Investigating The Effect of Argument-Driven Inquiry in Laboratory Instruction. Educational Sciences: Theory \& Practice. 15 (1), 267-283

[7] Walker, J.P. and Sampson, V. (2012). Argument-Driven Inquiry as a Way to Help Undergraduate Students Write to Learn by Learning to Write in Chemistry. International Journal of Science Education. 34 (10), 1443-1485

[8] Sampson,V., et.al. (2013). Writing to Learn by Learning to Write During the School Science Laboratory: Helping Middle and High School Students Develop Argumentative Writing Skills as They Learn Core Ideas. Science Education, 97 (5), 643-670.

[9] Sampson, V., Grooms, J., and Walker, J.P. (2010). Argument-Driven Inquiry as a Way to Help Students Learn How to Participate in Scientific Argumentation and Craft Written Arguments: An Exploratory Study. Science Education. 95 (2), 217-257.

[10] Kim, H. and Song, J. (2005) The Features of Peer Argumentation in Middle School Student's Scientific Inquiry. Research in Science Education. 36 (3), 211-233.

[11] Sampson, V., \& Clark, D. B. (2008). Assessment of the ways students generate arguments in science education: Current perspectives and recommendations for future directions. Science Education, 92, 447-472.

[12] Crowell, A and Kuhn,D. (2014). Development Dialogic Agumentation Skills: A 3-Year Intervention Study. Journal of Cognition and Development, 15 (2), 363-381.

[13] Zohar, A., and Dori, Y. J. (2003). Higher Order Thinking Skills and Low-achieving Students: Are They Mutually Exclusive? Journal of the Learning Sciences 12 (2), 145-181.

[14] Erduran, S., Simon, S., and Osborne, J. (2004). "TAPping into Argumentation: Developments in the Application of Toulmin's Argument Pattern for Studying Science Discourse". Science Education.88 (1), 915-933.

[15] Andriani,Y. (2015). Penggunaan Model Pembelajaran ArgumentDrivent Inquiry Dalam Mengembangkan Kemampuan Argumentasi Ilmiah And Penguasaan Konsep Siswa Pada Pembelajaran IPA Terpadu Di SMP Kelas VII.Tesis.Magister of Science Education UPI:Not Published. 